\title{
A VALIDATED REVERSED-PHASE HIGH-PERFORMANCE LIQUID CHROMATOGRAPHY METHOD FOR SIMULTANEOUS DETERMINATION OF FIVE ANTIEPILEPTIC DRUGS USED IN THE TREATMENT OF LENNOX-GASTAUT SYNDROME IN THEIR PHARMACEUTICAL DOSAGE FORMS
}

\author{
SONIA T HASSIB, HANAA M A HASHEM, MARIANNE A MAHROUSE, EMAN A MOSTAFA* \\ Department of Pharmaceutical Chemistry, Faculty of Pharmacy, Cairo University, Kasr El-Aini St., Cairo 11562, Egypt. \\ Email: dr.emanams@yahoo.com
}

Received: 06 December 2017, Revised and Accepted: 25 January 2018

\begin{abstract}
Objective: Lennox-Gastaut syndrome (LGS) is mainly treated with antiepileptic drugs (AEDs) but using one AED is not sufficient to relieve all or even most patients. A combination of agents is usually preferred. In the current study, an isocratic, selective, sensitive, precise, and accurate reversed-phase high-performance liquid chromatography (RP-HPLC) method was developed for the simultaneous determination of rufinamide (RUF), lamotrigine (LAM), clonazepam (CLO), valproic acid (VAL), and diazepam (DIA) which are commonly used in the management of LGS in their dosage forms using lacosamide as internal standard.
\end{abstract}

Methods: The method depends on using RESTEK $\mathrm{C}_{18}$ column $(5 \mu \mathrm{m}, 250 \mathrm{~mm} \times 4.6 \mathrm{~mm})$ and a mobile phase composed of acetonitrile:water (55: $45, \mathrm{v} / \mathrm{v}$ ), $\mathrm{pH}=3.3$ adjusted with phosphoric acid. The method was conducted in an isocratic mode with a flow rate of $1 \mathrm{ml} / \mathrm{min}$ and ultraviolet detection at $210 \mathrm{~nm}$.

Results: The linearity range was $2-40 \mu \mathrm{g} / \mathrm{ml}$ for RUF and DIA, $0.5-40 \mu \mathrm{g} / \mathrm{ml}$ for LAM and CLO, and 36-180 $\mu \mathrm{g} / \mathrm{ml}$ for VAL.

Conclusion: Statistical analysis revealed no significant difference between the results obtained and the official or reported ones for each cited drug. The method is simple to be easily implemented in quality control studies of the mentioned drugs in their pharmaceutical preparations.

Keywords: Rufinamide, Lamotrigine, Clonazepam, Valproic acid, Diazepam, High-performance liquid chromatography, Dosage form.

(C) 2018 The Authors. Published by Innovare Academic Sciences Pvt Ltd. This is an open access article under the CC BY license (http://creativecommons. org/licenses/by/4. 0/) DOI: http://dx.doi.org/10.22159/ajpcr.2018.v11i5.24143

\section{INTRODUCTION}

Lennox-Gastaut syndrome (LGS) is a severe form of childhood epileptic encephalopathy with multiple etiologies, whether genetic, structural, metabolic, or unknown. LGS could be diagnosed by EEG, usually demonstrating high voltage, bifrontal $1.5-2.5 \mathrm{~Hz}$ spikes, and wave complexes. Several seizure types are associated with LGS including sudden tonic-atonic seizures (drop attacks), atypical absence (the most common), myoclonic seizures, generalized tonic-clonic seizures, and partial onset seizures. The optimum treatment for LGS has yet to be established [1-4]. Treatment is aimed at reducing seizure burden using the least number of medications while minimizing side effects. However, seizure freedom is rare, and multiple anticonvulsants are often required. Surveys have shown that valproate is often the preferred drug for initial therapy. Either lamotrigine (LAM) or topiramate or rufinamide (RUF) is often the second-line choice for monotherapy if valproate is not efficacious. BZDs have been used as parenteral or rectal agent (diazepam [DIA], lorazepam, and midazolam) in acute cases, while for chronic oral use, clobazam, clonazepam [CLO], clorazepate, and nitrazepam were used. BZDs remain, in most guidelines, the treatment of choice for acute or subacute seizures [5-15].

On searching literature, it was found that many high-performance liquid chromatography (HPLC) methods were recently reported for the determination of RUF (Fig. 1a) [16-19], LAM (Fig. 1b) [20-23], CLO (Fig. 1c) [24,25], DIA (Fig. 1d) [26-28], and valproic acid (VAL) (Fig. 1e) [29-32] in their dosage forms. No method was reported for the simultaneous determination of the five cited drugs yet. The aim of the current work was to develop a sensitive, selective, and precise chromatographic method able to separate and quantify the cited drugs in their dosage forms. This method could also be used in the assays of the cited drugs in biological fluids as it covers their therapeutic ranges.

\section{EXPERIMENTAL}

\section{Instrumentation}

An HPLC instrument (Agilent 1100 series) was equipped with an Agilent isocratic pump G1310A, Agilent ultraviolet (UV)-visible detector G1314A, an Agilent manual injector G1328B with $(20 \mu \mathrm{l})$ injector loop and RESTEK $C_{18}$ column $(5 \mu \mathrm{m}, 4.6 \times 250 \mathrm{~mm}$, made in USA). An Agilent syringe ( $50 \mu \mathrm{l}, \mathrm{USA})$ and a Powersonic 405 ultrasonic processor (Human Lab INC - Hwaseong City, Korea) were employed. The $\mathrm{pH}$ measurements were carried out using a $\mathrm{pH}$ meter (Jenway, 3505, Essex, U.K.). The mobile phase was filtered through $0.45 \mu \mathrm{m}$ nylon membrane filters (Sigma-Aldrich Co., Germany).

\section{Materials and reagents}

RUF (its purity was certified as $99.45 \%$ ) and lacosamide, used as internal standard (IS) (Fig. 1f), were purchased from Wuhan Sunrise Technology Development Company, Wuhan, China. DIA, LAM, CLO, and VAL were supplied by the National Organization for Drug Control and Research, Egypt (certified to contain 99.91\%, 99.98\%, 99.53\%, and $100.10 \%$, respectively). Prepared Banzel ${ }^{\circledR}$ tablets were used because of its unavailability in the local market while Valium ${ }^{\circledR}$ ampoules (labelled to contain $10 \mathrm{mg}$ of DIA per ampoule) were manufactured by Roche, Lamictal $^{\mathrm{TM}}$ tablets (labelled to contain $25 \mathrm{mg}$ of LAM per tablet, Batch No. AC0602) were manufactured by GlaxoSmithKline Pharmaceuticals, Apetryl ${ }^{\circledR}$ tablets (labelled to contain $0.5 \mathrm{mg}$ of CLO per tablet) were manufactured by APEX Pharma, and Depakine ${ }^{\circledR}$ tablets (labelled to contain $200 \mathrm{mg}$ of sodium valproate per tablet equivalent to $173.49 \mathrm{mg}$ 
<smiles>NC(=O)c1cn(Cc2c(F)cccc2F)nn1</smiles>

a<smiles>O=C1CN=C(c2ccccc2Cl)c2cc([N+](=O)[O-])ccc2N1</smiles>

c<smiles>CCCC(CCC)C(=O)O</smiles>

e b<smiles>Nc1nnc(-c2cccc(Cl)c2Cl)c(N)n1</smiles>

d<smiles>COC[C@H](NC(C)=O)C(=O)NCc1ccccc1</smiles>

Fig. 1: Chemical structures of rufinamide (a), lamotrigine (b), clonazepam (c), diazepam (d), valproic (e), and lacosamide (IS) (f)

of VAL, Batch No. C13958) were manufactured by SANOFI and were purchased from the local market. Acetonitrile (HPLC grade) was supplied from Sigma-Aldrich, Germany. Double-distilled water was used after filtration through $0.45 \mu \mathrm{m}$ nylon membrane filters. $o$-phosphoric acid (EL-Nasr Pharmaceutical Chemicals Co., Egypt) was prepared as $0.01 \mathrm{~N}$ aqueous solution.

\section{Chromatographic conditions}

Chromatographic separation was achieved on RESTEK $\mathrm{C}_{18}$ column ( $5 \mu \mathrm{m}, 4.6 \times 250 \mathrm{~mm}$ ), applying isocratic elution using a mobile phase consisting of acetonitrile:water $(55: 45, \mathrm{v} / \mathrm{v}$, adjusted with $0.01 \mathrm{~N}$ aqueous solution of $o$-phosphoric acid to $\mathrm{pH}=3.3$ ). The mobile phase was filtered through a membrane filter of $0.45 \mu \mathrm{m}$ porosity and pumped through the column at a flow rate of $1 \mathrm{ml} / \mathrm{min}$. Analysis was performed at ambient temperature, and the UV detector was set at $210 \mathrm{~nm}$.

\section{Stock and working solutions preparation}

Standard stock solutions of $(200 \mu \mathrm{g} / \mathrm{ml})$ for RUF, LAM, CLO, DIA, and IS and also a stock solution of $(9 \mathrm{mg} / \mathrm{ml})$ for VAL were prepared in acetonitrile by transferring an accurately weighed amount of each drug in a series of $50 \mathrm{ml}$ volumetric flask, adding $25 \mathrm{ml}$ acetonitrile, then the mixture was sonicated and the flask was completed to volume with the same solvent. For the preparation of working solutions of $50 \mu \mathrm{g} / \mathrm{ml}$ for RUF, LAM, CLO, and DIA, $25 \mathrm{ml}$ was transferred from the stock solution of each drug into a $100 \mathrm{ml}$ volumetric flask and completed with acetonitrile to volume. Furthermore, two working solutions of $900 \mu \mathrm{g} / \mathrm{ml}$ and $100 \mu \mathrm{g} / \mathrm{ml}$ for VAL and IS, respectively, were prepared similarly.

\section{Sample preparation}

Twenty tablets of Depakine ${ }^{\circledR}$, Apetryl ${ }^{\circledR}$, Lamictal ${ }^{\circledR}$, and Banzel ${ }^{\circledR}$ were separately weighed and finely powdered. A quantity of each powdered tablets equivalent to $10 \mathrm{mg}$ of VAL (equivalent to $11.53 \mathrm{mg}$ of sodium valproate), CLO, LAM, and RUF, respectively, was accurately weighed, $25 \mathrm{ml}$ of acetonitrile was added, and each drug was extracted by sonication for $15 \mathrm{~min}$. The volume was completed to $50 \mathrm{ml}$ with acetonitrile; the solution was mixed well and filtered on dry funnel and dry filter paper discarding the first few milliliters to obtain a sample stock solution of $200 \mu \mathrm{g} / \mathrm{ml}$. Further, dilution was carried out using acetonitrile to obtain sample working solutions of $50 \mu \mathrm{g} / \mathrm{ml}$ of CLO, LAM, and RUF and $90 \mu \mathrm{g} / \mathrm{ml}$ of VAL. Furthermore, one ampoule of valium was transferred to a $50 \mathrm{ml}$ volumetric flask, and the volume was completed with acetonitrile to prepare a sample stock solution of $(200 \mu \mathrm{g} / \mathrm{ml})$ from which a sample working solution of $50 \mu \mathrm{g} / \mathrm{ml}$ of DIA was also prepared in the same manner.

\section{General procedures and linearity}

Accurately measured aliquots of RUF, DIA, LAM, and CLO standard solutions $(50 \mu \mathrm{g} / \mathrm{ml})$ equivalent to $20-400 \mu \mathrm{g}$ of RUF and DIA and 5-400 $\mu \mathrm{g}$ of LAM and CLO, respectively, were transferred into a series of $10 \mathrm{ml}$ volumetric flasks and completed to volume with acetonitrile. Furthermore, different aliquots were transferred from VAL standard solution $(90 \mu \mathrm{g} / \mathrm{ml})$ to produce solutions of the concentration range of $36-180 \mu \mathrm{g} / \mathrm{ml}$. A volume of $20 \mu \mathrm{l}$ of each solution was injected in triplicates into the chromatograph. The chromatographic conditions were adjusted as mentioned under section chromatographic conditions. The recorded AUPs $\times 10^{-3}$ were plotted versus the corresponding 
concentrations of RUF, DIA, LAM, CLO, and VAL to obtain the calibration curves.

\section{RESULTS AND DISCUSSION}

Method development

The current work aimed to develop an accurate, sensitive, and precise chromatographic method to separate and simultaneously determine RUF, DIA, LAM, CLO, and VAL. A variety of mobile phases were investigated in the development of the present method where different proportions of methanol: Water and acetonitrile: Water and phosphate buffer: Acetonitrile at different $\mathrm{pH}$ was attempted as mobile phases, but it was found that the presence of buffer is not needed. The use of acidified water was satisfactory for the separation of the peaks, but adjusting the $\mathrm{pH}$ was a very important step due to the big differences in $\mathrm{pKa}$ of the cited drugs. Finally, a mobile phase composed of acetonitrile:water (55: $45, \mathrm{v} / \mathrm{v}), \mathrm{pH}=3.3$ adjusted with phosphoric acid, was satisfactory to achieve the separation and resulted in symmetric peaks of the cited drugs with good retention times. The detection wavelength was selected to be $210 \mathrm{~nm}$ which is suitable for the determination of the cited drugs as it represents the maximum absorption wavelength of each drug. By adjusting all the chromatographic conditions, a good separation of RUF, DIA, LAM, CLO, and VAL using lacosamide as IS was achieved with the following retention times: 3.102, 8.365, 4.235, 4.879, 7.242, and 3.712 for IS, respectively (Fig. 2).

\section{Method validation}

The optimized chromatographic method was validated by evaluating linearity, accuracy, precision, limit of detection (LOD), limit of quantification (LOQ), specificity, and system suitability parameters in accordance with the ICH guideline Q2 (R1) [33].

\section{Linearity}

The linearity was investigated at six concentration levels of the standard solutions of RUF, DIA, LAM, CLO, and VAL; each concentration was analyzed 3 times. The linearity was evaluated by linear regression analysis. The correlation coefficients were 0.9998 for RUF, DIA and VAL, 0.9999 for CLO, and 0.9992 for LAM, respectively. The analytical data of the calibration curves including standard deviations (SD) for the slope $\left(\mathrm{S}_{\mathrm{b}}\right)$ and intercept $\left(\mathrm{S}_{\mathrm{a}}\right)$, confidence limits of the slope, and intercept are summarized in Table 1.

\section{Accuracy}

The accuracy of the proposed method was tested by analyzing triplicate samples of standard solutions of each cited drug. The recovery percentages are stated in Table 2, and the results revealed the high accuracy of the proposed method. Furthermore, method accuracy was assessed as recovery obtained when spiking the sample solution with known concentrations of the cited drugs (standard addition technique) as shown in Tables 3-7.

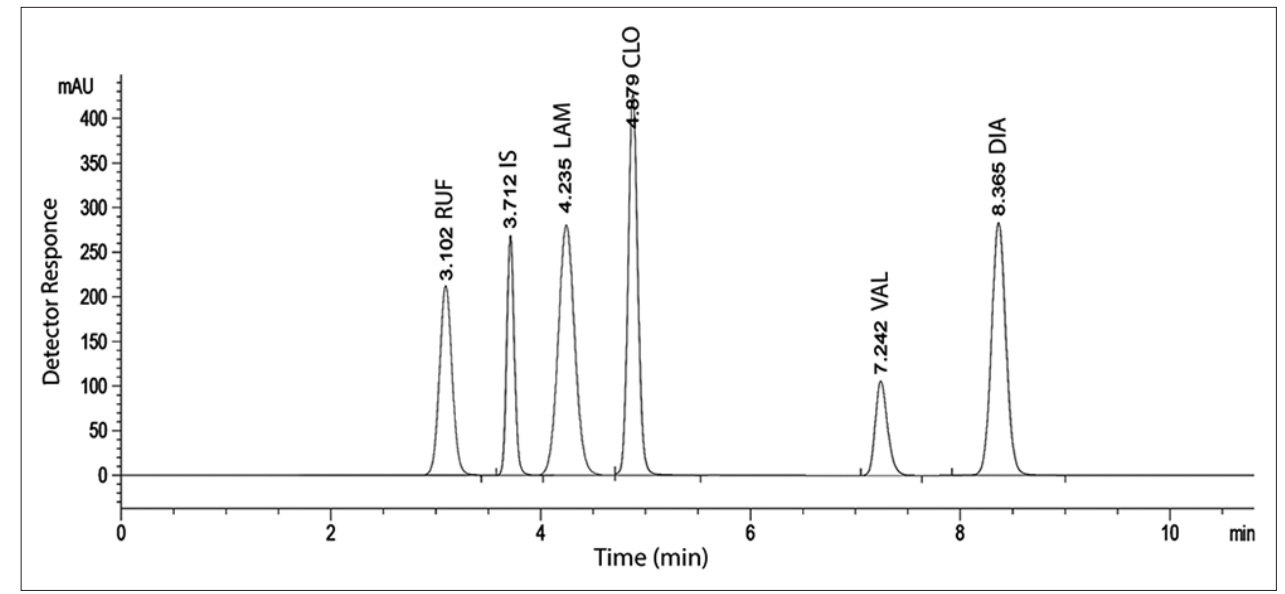

Fig. 2: High-performance liquid chromatogram of rufinamide, lamotrigine, clonazepam, diazepam, valproic acid, and lacosamide (IS) in their laboratory prepared mixture

Table 1: Validation parameters and results obtained by the proposed RP-HPLC method for the simultaneous determination of RUF, DIA, LAM, CLO, and VAL

\begin{tabular}{|c|c|c|c|c|c|}
\hline Item & RUF & DIA & LAM & CLO & VAL \\
\hline Retention time $\left(\mathrm{t}_{\mathrm{R}}\right)(\mathrm{min})$ & 3.102 & 8.365 & 4.235 & 4.879 & 7.242 \\
\hline Wavelength of detection (nm) & 210 & 210 & 210 & 210 & 210 \\
\hline Range of linearity & $2-40 \mu \mathrm{g} / \mathrm{ml}$ & $2-40 \mu \mathrm{g} / \mathrm{ml}$ & $0.5-40 \mu \mathrm{g} / \mathrm{ml}$ & $0.5-40 \mu \mathrm{g} / \mathrm{ml}$ & $36-180 \mu \mathrm{g} / \mathrm{ml}$ \\
\hline \multirow[t]{2}{*}{ Regression equation } & $\mathrm{PAR}=0.1004$ & $\mathrm{PAR}=0.1296$ & $\mathrm{PAR}=0.1048$ & $\mathrm{PAR}=0.1310$ & $\mathrm{PAR}=0.0097$ \\
\hline & $\mathrm{C}_{\mathrm{RUF}}-0.0781$ & $\mathrm{C}_{\mathrm{DIA}}+0.1078$ & $\mathrm{C}_{\text {LAM }}+0.0880$ & $\mathrm{C}_{\mathrm{CLO}}+0.0612$ & $\mathrm{C}_{\mathrm{VAL}}+0.0172$ \\
\hline Regression coefficient $\left(\mathrm{r}^{2}\right)$ & 0.9998 & 0.9998 & 0.9992 & 0.9999 & 0.9998 \\
\hline $\mathrm{LOD}(\mu \mathrm{g} / \mathrm{ml})$ & 0.5263 & 0.4226 & 0.1362 & 0.1258 & 5.4411 \\
\hline SD of the slope $(\mathrm{Sb})$ & 0.0007 & 0.0009 & 0.0015 & 0.0007 & 0.0001 \\
\hline Standard deviation of the intercept (Sa) & 0.0160 & 0.0199 & 0.0340 & 0.0159 & 0.0094 \\
\hline Confidence limit of the slope & $0.1004 \pm 0.0020$ & $0.1296 \pm 0.0025$ & $0.1048 \pm 0.0042$ & $0.1310 \pm 0.0020$ & $0.0097 \pm 0.0002$ \\
\hline Confidence limit of the intercept & $-0.0781 \pm 0.0444$ & $0.1078 \pm 0.0552$ & $0.0880 \pm 0.0946$ & $0.0612 \pm 0.0443$ & $0.0172 \pm 0.0262$ \\
\hline Standard error of estimation & 0.0238 & 0.0296 & 0.0538 & 0.0252 & 0.0095 \\
\hline *Intraday \% RSD & $0.136-0.600$ & $0.120-0.372$ & $0.060-0.255$ & $0.252-0.483$ & $0.144-0.974$ \\
\hline *Interday \% RSD & $0.153-0.456$ & $0.084-0.774$ & $0.129-0.779$ & $0.431-0.658$ & $0.166-0.312$ \\
\hline
\end{tabular}

*PAR: Peak area ratio, ${ }^{* *} \mathrm{LOD}: 3.3 * \mathrm{SD} /$ slope, ${ }^{* * *} \mathrm{LOQ}: 10^{*} \mathrm{SD} /$ slope. ${ }^{* * * *}$ The intraday $(\mathrm{n}=3)$, average of three concentrations of 3,15 , and $35 \mu \mathrm{g} / \mathrm{ml}$ for RUF and DIA, 1.5, 15, and $35 \mu \mathrm{g} / \mathrm{ml}$ for LAM and CLO, and 45, 135, and $171 \mu \mathrm{g} / \mathrm{ml}$ for VAL repeated 3 times within the day. ${ }^{* * * * *}$ The interday (n=3), average of three concentrations of 3,15 , and $35 \mu \mathrm{g} / \mathrm{ml}$ for RUF and DIA, 1.5, 15, and $35 \mu \mathrm{g} / \mathrm{ml}$ for LAM and CLO, and 45, 135, and $171 \mu \mathrm{g} / \mathrm{ml}$ for VAL repeated 3 times in 3 successive days. RP-HPLC: Reversed-phase high-performance liquid chromatography, RUF: Rufinamide, LAM: Lamotrigine, CLO: Clonazepam, DIA: Diazepam, VAL: Valproic acid, LOD: Limit of detection, LOQ: Limit of quantification, SD: Standard deviations 
Table 2: Determination of RUF, DIA, LAM, CLO, and VAL in drug substance using the proposed RP-HPLC method

\begin{tabular}{|c|c|c|c|c|c|c|c|c|c|c|c|c|c|c|c|c|c|}
\hline \multirow{2}{*}{$\begin{array}{l}\text { Taken } \\
(\mu \mathrm{g} / \mathrm{ml})\end{array}$} & \multicolumn{2}{|l|}{ PAR } & \multirow{2}{*}{$\begin{array}{l}\text { Taken } \\
(\mu \mathrm{g} / \mathrm{ml})\end{array}$} & \multicolumn{2}{|l|}{ PAR } & \multirow{2}{*}{$\begin{array}{l}\text { Taken } \\
(\mu \mathrm{g} / \mathrm{ml})\end{array}$} & \multirow{2}{*}{$\frac{\text { PAR }}{\text { VAL }}$} & \multicolumn{5}{|c|}{ Found $(\mu \mathrm{g} / \mathrm{ml})$} & \multicolumn{5}{|c|}{ Recovery \% } \\
\hline & RUF & DIA & & LAM & CLO & & & RUF & DIA & LAM & CLO & VAL & RUF & DIA & LAM & CLO & VAL \\
\hline 4 & 0.322 & 0.623 & 1 & 0.192 & 0.191 & 54 & 0.541 & 3.99 & 3.98 & 0.99 & 0.99 & 54.00 & 99.63 & 99.38 & 99.20 & 99.10 & 100.00 \\
\hline 8 & 0.718 & 1.131 & 12 & 1.351 & 1.623 & 108 & 1.058 & 7.93 & 7.90 & 12.05 & 11.92 & 107.30 & 99.11 & 98.69 & 100.43 & 99.35 & 99.35 \\
\hline 16 & 1.527 & 2.179 & 18 & 1.983 & 2.410 & 117 & 1.149 & 15.99 & 15.98 & 18.08 & 17.93 & 116.68 & 99.92 & 99.88 & 100.46 & 99.61 & 99.73 \\
\hline 24 & 2.317 & 3.210 & 24 & 2.587 & 3.202 & 126 & 1.236 & 23.86 & 23.94 & 23.85 & 23.98 & 125.65 & 99.40 & 99.74 & 99.35 & 99.90 & 99.72 \\
\hline \multirow[t]{4}{*}{32} & 3.113 & 4.238 & 32 & 3.421 & 4.234 & 153 & 1.487 & 31.78 & 31.87 & 31.80 & 31.85 & 151.53 & 99.33 & 99.59 & 99.38 & 99.54 & 99.04 \\
\hline & & & & & & & & & & & & Mean & 99.59 & 99.41 & 100.00 & 99.51 & 99.62 \\
\hline & & & & & & & & & & & & $\pm \mathrm{SD}$ & 0.381 & 0.432 & 0.796 & 0.269 & 0.360 \\
\hline & & & & & & & & & & & & $\pm \mathrm{RSD}$ & 0.382 & 0.435 & 0.796 & 0.270 & 0.362 \\
\hline
\end{tabular}

RP-HPLC: Reversed-phase high-performance liquid chromatography, RUF: Rufinamide, LAM: Lamotrigine, CLO: Clonazepam, DIA: Diazepam, VAL: Valproic acid, SD: Standard deviations

Table 3: Determination of RUF in Banzel ${ }^{\circledR}$ tablets applying standard addition technique using the proposed RP-HPLC method

\begin{tabular}{|c|c|c|c|c|c|c|c|c|}
\hline \multicolumn{2}{|c|}{ Taken $(\mu \mathrm{g} / \mathrm{ml})$} & \multicolumn{2}{|l|}{ PAR } & \multicolumn{3}{|c|}{ Found $(\mu \mathrm{g} / \mathrm{ml})$} & \multicolumn{2}{|c|}{ Recovery \% } \\
\hline Tablet & Added & Tablet & Tablet and added & Tablet & Tablet and added & Added & Tablet & Added \\
\hline 5 & 5 & 0.425 & 0.929 & 5.01 & 10.03 & 5.02 & 100.22 & 100.40 \\
\hline 5 & 6 & 0.425 & 1.030 & 5.01 & 11.04 & 6.03 & 100.22 & 100.43 \\
\hline 10 & 8 & 0.924 & 1.736 & 9.98 & 18.07 & 8.09 & 99.81 & 101.10 \\
\hline 10 & 12 & 0.924 & 2.142 & 9.98 & 22.11 & 12.13 & 99.81 & 101.10 \\
\hline 20 & 16 & 1.943 & 3.569 & 20.13 & 36.33 & 16.20 & 100.65 & 101.23 \\
\hline \multirow[t]{4}{*}{20} & 20 & 1.943 & 3.956 & 20.13 & 40.18 & 20.05 & 100.65 & 100.25 \\
\hline & & & & & & Mean & 100.23 & 100.75 \\
\hline & & & & & & $\pm \mathrm{SD}$ & 0.420 & 0.436 \\
\hline & & & & & & $\pm \mathrm{RSD}$ & 0.419 & 0.433 \\
\hline
\end{tabular}

RP-HPLC: Reversed-phase high-performance liquid chromatography, RUF: Rufinamide, SD: Standard deviations

Table 4: Determination of DIA in Valium ${ }^{\circledR}$ ampoules applying standard addition technique using the proposed RP-HPLC method

\begin{tabular}{|c|c|c|c|c|c|c|c|c|}
\hline \multicolumn{2}{|c|}{ Taken $(\mu \mathrm{g} / \mathrm{ml})$} & \multicolumn{2}{|l|}{ PAR } & \multicolumn{3}{|c|}{ Found $(\mu \mathrm{g} / \mathrm{ml})$} & \multicolumn{2}{|c|}{ Recovery \% } \\
\hline Ampoule & Added & Ampoule & Ampoule and added & Ampoule & Ampoule and added & Added & Ampoule & Added \\
\hline 5 & 5 & 0.750 & 1.397 & 4.96 & 9.948 & 4.99 & 99.10 & 99.86 \\
\hline 5 & 6 & 0.750 & 1.531 & 4.96 & 10.981 & 6.03 & 99.10 & 100.43 \\
\hline 10 & 8 & 1.396 & 2.444 & 9.94 & 18.026 & 8.09 & 99.40 & 101.08 \\
\hline 10 & 12 & 1.396 & 2.963 & 9.94 & 22.031 & 12.09 & 99.40 & 100.76 \\
\hline 20 & 16 & 2.693 & 4.781 & 19.95 & 36.059 & 16.11 & 99.74 & 100.69 \\
\hline \multirow[t]{4}{*}{20} & 20 & 2.693 & 5.308 & 19.95 & 40.125 & 20.18 & 99.74 & 100.89 \\
\hline & & & & & & Mean & 99.41 & 100.62 \\
\hline & & & & & & $\pm \mathrm{SD}$ & 0.320 & 0.430 \\
\hline & & & & & & $\pm \mathrm{RSD}$ & 0.322 & 0.427 \\
\hline
\end{tabular}

RP-HPLC: Reversed-phase high-performance liquid chromatography, DIA: Diazepam, SD: Standard deviations

Table 5: Determination of LAM in Lamictal ${ }^{\circledR}$ tablets applying standard addition technique using the proposed RP-HPLC method

\begin{tabular}{|c|c|c|c|c|c|c|c|c|}
\hline \multicolumn{2}{|c|}{ Taken $(\mu \mathrm{g} / \mathrm{ml})$} & \multicolumn{2}{|l|}{ PAR } & \multicolumn{3}{|c|}{ Found $(\mu \mathrm{g} / \mathrm{ml})$} & \multicolumn{2}{|c|}{ Recovery \% } \\
\hline Tablet & Added & Tablet & Tablet and added & Tablet & Tablet and added & Added & Tablet & Added \\
\hline 2 & 1.6 & 0.297 & 0.464 & 1.99 & 3.59 & 1.59 & 99.70 & 99.63 \\
\hline 2 & 2 & 0.297 & 0.508 & 1.99 & 4.01 & 2.01 & 99.70 & 100.70 \\
\hline 5 & 5 & 0.605 & 1.133 & 4.93 & 9.97 & 5.04 & 98.66 & 100.82 \\
\hline 5 & 6 & 0.605 & 1.234 & 4.93 & 10.94 & 6.01 & 98.66 & 100.08 \\
\hline 10 & 8 & 1.117 & 1.956 & 9.82 & 17.82 & 8.01 & 98.19 & 100.06 \\
\hline \multirow[t]{4}{*}{10} & 12 & 1.117 & 2.358 & 9.82 & 21.66 & 11.84 & 98.19 & 98.68 \\
\hline & & & & & & Mean & 98.85 & 100.00 \\
\hline & & & & & & $\pm \mathrm{SD}$ & 0.773 & 0.781 \\
\hline & & & & & & $\pm \mathrm{RSD}$ & 0.782 & 0.781 \\
\hline
\end{tabular}

RP-HPLC: Reversed-phase high-performance liquid chromatography, LAM: Lamotrigine, SD: Standard deviations

Precision

The precision of the developed method was checked by analyzing three different concentrations of the cited drugs in triplicate during the same day (intraday precision) and on 3 consecutive days (interday precision). The results are presented in Table 1.

\section{Specificity}

Specificity was established by analyzing the cited drugs in laboratory prepared mixtures containing different ratios of the cited drugs. Specificity was also checked by analyzing each drug in its dosage form separately showing no interference from excipients (Fig. 3). The use 
Table 6: Determination of CLO in Apetry ${ }^{\oplus}$ tablets applying standard addition technique using the proposed RP-PLC method

\begin{tabular}{|c|c|c|c|c|c|c|c|c|}
\hline \multicolumn{2}{|c|}{ Taken $(\mu \mathrm{g} / \mathrm{ml})$} & \multicolumn{2}{|l|}{ PAR } & \multicolumn{3}{|c|}{ Found $(\mu \mathrm{g} / \mathrm{ml})$} & \multicolumn{2}{|c|}{ Recovery \% } \\
\hline Tablet & Added & Tablet & Tablet and added & Tablet & Tablet and added & Added & Tablet & Added \\
\hline 2 & 1.6 & 0.321 & 0.530 & 1.98 & 3.58 & 1.60 & 99.15 & 99.75 \\
\hline 5 & 5 & 0.715 & 1.370 & 4.99 & 9.99 & 5.00 & 99.82 & 100.02 \\
\hline 5 & 6 & 0.715 & 1.495 & 4.99 & 10.95 & 5.96 & 99.82 & 99.25 \\
\hline 10 & 8 & 1.360 & 2.397 & 9.92 & 17.83 & 7.92 & 99.15 & 98.95 \\
\hline \multirow[t]{4}{*}{10} & 12 & 1.360 & 2.928 & 9.92 & 21.88 & 11.97 & 99.15 & 99.74 \\
\hline & & & & & & Mean & 99.37 & 99.56 \\
\hline & & & & & & $\pm \mathrm{SD}$ & 0.387 & 0.389 \\
\hline & & & & & & $\pm \mathrm{RSD}$ & 0.389 & 0.391 \\
\hline
\end{tabular}

RP-HPLC: Reversed-phase high-performance liquid chromatography, CLO: Clonazepam, SD: Standard deviations

Table 7: Determination of VAL in Depakine ${ }^{\circledR}$ tablets applying standard addition technique using the proposed RP-HPLC method

\begin{tabular}{|c|c|c|c|c|c|c|c|c|}
\hline \multicolumn{2}{|c|}{ Taken $(\mu \mathrm{g} / \mathrm{ml})$} & \multicolumn{2}{|l|}{ PAR } & \multicolumn{3}{|c|}{ Found $(\mu \mathrm{g} / \mathrm{ml})$} & \multicolumn{2}{|c|}{ Recovery \% } \\
\hline Tablet* & Added & Tablet & Tablet and added & Tablet & Tablet and added & Added & Tablet & Added \\
\hline 36 & 36 & 0.366 & 0.713 & 35.96 & 71.73 & 35.77 & 99.89 & 99.37 \\
\hline 72 & 54 & 0.712 & 1.229 & 71.63 & 124.93 & 53.30 & 99.48 & 98.70 \\
\hline 72 & 72 & 0.712 & 1.398 & 71.63 & 142.35 & 70.72 & 99.48 & 98.23 \\
\hline 90 & 72 & 0.884 & 1.576 & 89.36 & 160.70 & 71.34 & 99.29 & 99.08 \\
\hline \multirow[t]{4}{*}{90} & 90 & 0.884 & 1.746 & 89.36 & 178.23 & 88.87 & 99.29 & 98.74 \\
\hline & & & & & & Mean & 99.55 & 98.96 \\
\hline & & & & & & $\pm \mathrm{SD}$ & 0.307 & 0.514 \\
\hline & & & & & & $\pm \mathrm{RSD}$ & 0.308 & 0.519 \\
\hline
\end{tabular}

*The concentrations mentioned above of sodium valproate are expressed in its equivalence of VAL. RP-HPLC: Reversed-phase high-performance liquid chromatography, VAL: Valproic, SD: Standard deviations

Table 8: Determination of RUF, DIA, LAM, CLO, and VAL in laboratory prepared mixtures using the proposed RP-HPLC method

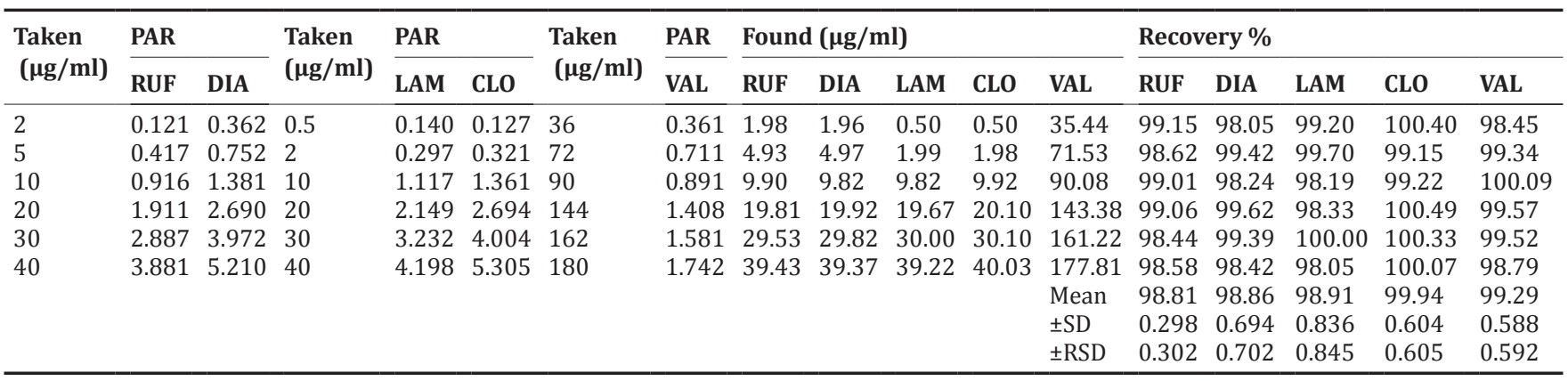

SD: Standard deviation, RP-HPLC: Reversed-phase high-performance liquid chromatography, RUF: Rufinamide, LAM: Lamotrigine, CLO: Clonazepam, DIA: Diazepam, VAL: Valproic

of phosphoric acid in the mobile phase liberates VAL from sodium valproate in its dosage form which results in a peak with the same retention time as VAL in drug substance (Fig. 3). The good recovery $\%$ and low SD proved the high specificity of the proposed method (Table 8).

\section{LOD and LOQ}

According to the ICH recommendations [33], the parameters LOD and LOQ were determined on the basis of SD of the response and slope of the regression equation, Table 1.

\section{System suitability}

The system suitability parameters with respect to the number of theoretical plates, resolution factor, tailing factor, capacity factor, and selectivity factor were displayed in Table 9.

\section{Statistics}

The proposed analytical method was compared with the reference methods of the cited drugs [19] using statistical analysis. The Student's t-test and F-test were applied and revealed no significant difference between the experimental values obtained in the pure sample analysis by the newly developed method and that of the references methods (Table 10).

\section{CONCLUSION}

The proposed RP-HPLC method was accurate, precise, selective, and sensitive. It allows the simultaneous separation and determination of five anti-epileptic drugs: RUF, DIA, LAM, CLO, and VAL in their pharmaceutical dosage forms using lacosamide as IS. The validation of the developed method according to the ICH guidelines proved the applicability and great value of this method for routine analysis in quality control laboratories for the determination of the cited drugs in their pure form and their dosage forms.

\section{CONFLICT OF INTEREST}

All of the authors declare that they have no conflict of interest. 
Table 9: System suitability tests of the proposed RP-HPLC method for the simultaneous determination of RUF, DIA, LAM, CLO, and VAL

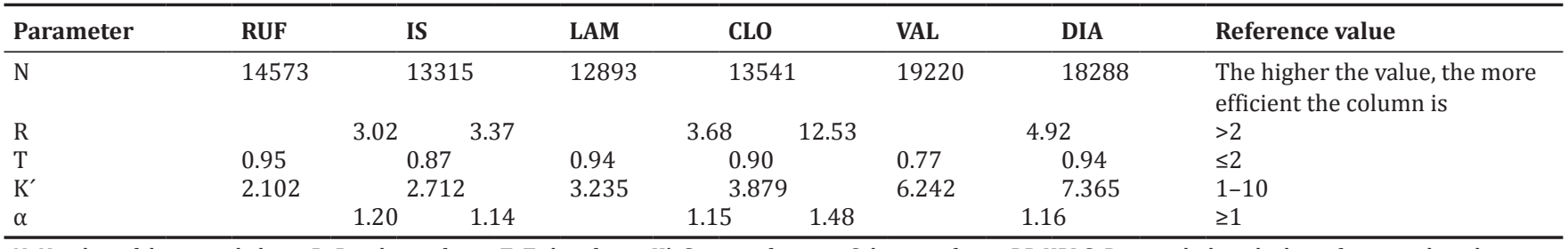

N: Number of theoretical plates, R: Resolution factor, T: Tailing factor, K': Capacity factor, $\alpha$ : Selectivity factor. RP-HPLC: Reversed-phase high-performance liquid chromatography, RUF: Rufinamide, LAM: Lamotrigine, CLO: Clonazepam, DIA: Diazepam, VAL: Valproic

Table 10: Statistical comparison between the proposed reversed-phase high-performance liquid chromatography method for the simultaneous determination of RUF, DIA, LAM, CLO, and VAL in drug substance and the reference methods

\begin{tabular}{|c|c|c|c|c|c|c|c|c|c|c|}
\hline $\begin{array}{l}\text { Statistical } \\
\text { term }\end{array}$ & $\begin{array}{l}\text { Reference } \\
\text { method } \\
\text { for } \text { RUF }^{1}\end{array}$ & $\begin{array}{l}\text { RUF by } \\
\text { RP-HPLC } \\
\text { method }\end{array}$ & $\begin{array}{l}\text { Reference } \\
\text { method for } \\
\text { DIA }^{2}\end{array}$ & $\begin{array}{l}\text { DIA by } \\
\text { RP-HPLC } \\
\text { method }\end{array}$ & $\begin{array}{l}\text { Reference } \\
\text { method for } \\
\text { LAM }^{3}\end{array}$ & $\begin{array}{l}\text { LAM by } \\
\text { RP-HPLC } \\
\text { method }\end{array}$ & $\begin{array}{l}\text { Reference } \\
\text { method for } \\
\text { CLO }^{4}\end{array}$ & $\begin{array}{l}\text { CLO by } \\
\text { RP-HPLC } \\
\text { method }\end{array}$ & $\begin{array}{l}\text { Reference } \\
\text { method } \\
\text { for VAL }{ }^{5}\end{array}$ & $\begin{array}{l}\text { VAL by } \\
\text { RP-HPLC } \\
\text { method }\end{array}$ \\
\hline Mean & 99.45 & 99.59 & 99.91 & 99.41 & 99.98 & 100.00 & 99.53 & 99.51 & 100.10 & 99.62 \\
\hline$\pm \mathrm{SD}$ & 0.779 & 0.381 & 0.936 & 0.432 & 0.927 & 0.796 & 0.356 & 0.269 & 0.744 & 0.360 \\
\hline$\pm \mathrm{SE}$ & 0.318 & 0.155 & 0.382 & 0.176 & 0.378 & 0.325 & 0.145 & 0.110 & 0.304 & 0.147 \\
\hline$\%$ RSD & 0.784 & 0.382 & 0.937 & 0.435 & 0.927 & 0.796 & 0.358 & 0.270 & 0.743 & 0.362 \\
\hline $\mathrm{n}$ & 6 & 6 & 6 & 6 & 6 & 6 & 6 & 6 & 6 & 6 \\
\hline $\mathrm{t}\left({ }^{*} 2.23\right)$ & & 0.40 & & 1.19 & & 0.68 & & 0.11 & & 1.42 \\
\hline $\mathrm{F}(* 5.05)$ & & 4.19 & & 4.69 & & 1.36 & & 1.75 & & 4.26 \\
\hline
\end{tabular}

*Figures in parentheses are the theoretical $t$ and $\mathrm{F}$ values at $\mathrm{p}=0.05 .{ }^{1} \mathrm{HPLC}$ method [19]. ${ }^{2}$ B.P. British Pharmacopoeia 2016: Non-aqueous titration. ${ }^{3} \mathrm{~B} . \mathrm{P}$. British Pharmacopoeia 2016: Non-aqueous titration. ${ }^{4}$ B.P. British Pharmacopoeia 2016: Non-aqueous titration. ${ }^{5}$ B.P. British Pharmacopoeia 2016: Non-aqueous titration, RP-HPLC: Reversed-phase high-performance liquid chromatography, RUF: Rufinamide, LAM: Lamotrigine, CLO: Clonazepam, DIA: Diazepam, VAL: Valproic

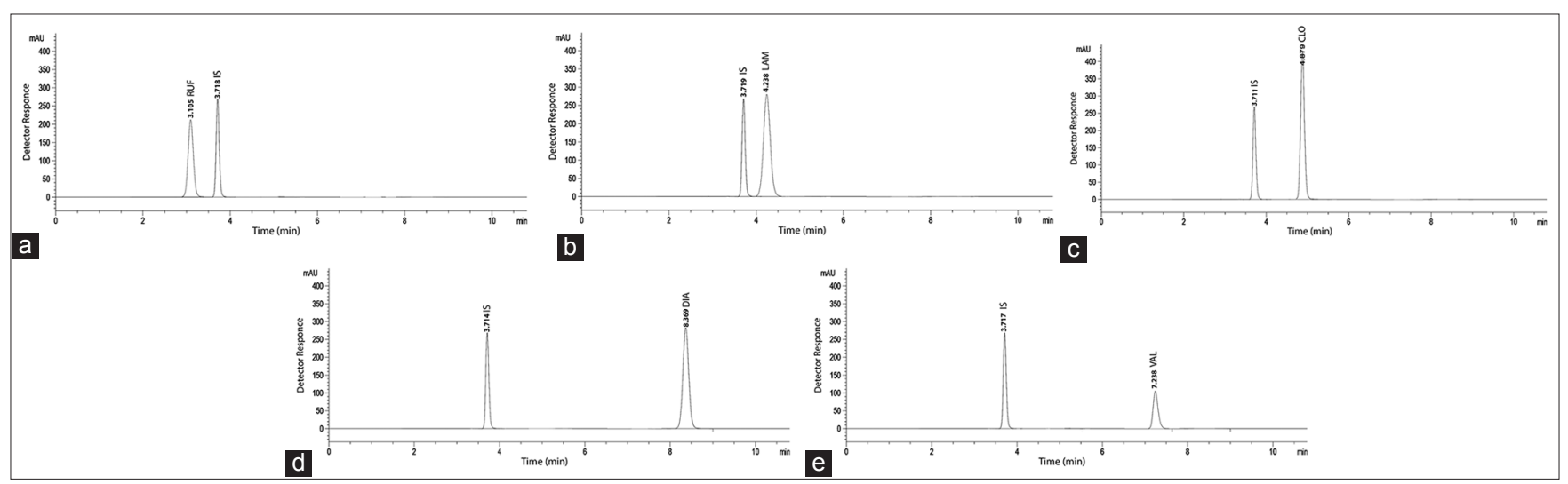

Fig. 3: High-performance liquid chromatography of rufinamide (a), lamotrigine (b), clonazepam (c), diazepam (d), and valproic (e) in their dosage forms

\section{REFERENCES}

1. Sharma S, Jain P, Gulati S, Sankhyan N, Agarwala A. Use of the modified atkins diet in lennox gastaut syndrome. J Child Neurol 2015;30:576-9.

2. Cramer JA, Sapin C, François C. Indirect comparison of clobazam and other therapies for lennox-gastaut syndrome. Acta Neurol Scand 2013;128:91-9.

3. Crumrine PK. Management of seizures in lennox-gastaut syndrome. Paediatr Drugs 2011;13:107-18.

4. Hancock EC, Cross HJ. Treatment of lennox-gastaut syndrome. Cochrane Database of Syst Rev 2009;3:CD003277.

5. Lemmon ME, Kossoff EH. New treatment options for lennox-gastaut syndrome. Curr Treat Options Neurol 2013;15:519-28.

6. Culy CR, Goa KL. Lamotrigine. A review of its use in childhood epilepsy. Paediatr Drugs 2000;2:299-330.

7. Montouris GD, Wheless JW, Glauser TA. The efficacy and tolerability of pharmacologic treatment options for lennox-gastaut syndrome. Epilepsia 2014;55 Suppl 4:10-20.

8. van Rijckevorsel K. Treatment of lennox-gastaut syndrome: Overview and recent findings. Neuropsychiatr Dis Treat 2008;4:1001-19.
9. Stafstrom CE. Update on the management of lennox-gastaut syndrome with a focus on rufinamide. Neuropsychiatr Dis Treat 2009;5:547-51.

10. Gresham J, Eiland LS, Chung AM. Treating lennox-gastaut syndrome in epileptic pediatric patients with third-generation rufinamide. Neuropsychiatr Dis Treat 2010;6:639-45.

11. Vijayakumar A, Pandian BG, Emilda MV, Mohan A. Study on prevalence of depression and adverse drug reactions among South Indian epileptic patients. Asian J Pharm Clin Res 2015;8:73-6.

12. Upadhyay J, Upadhyay G, Rana AJ. A prospective study on prevalence of epilepsy disorders and drug utilization pattern. Asian J Pharm Clin Res 2017;10:136-9.

13. Alsamman A, Othman M. Preparation and in vitro evaluation of fast release diazepam suppositories for febrile seizures. Asian J Pharm Clin Res 2017;10:224-30

14. Sarma P, Bhattacharyya A. Models of epilepsy used in antiepileptic drug discovery: A review. Int J Pharm Pharm Sci 2014;6:1-7.

15. Pasha I, Kamate M, Suresh DK. Effect of lacosamide on behaviour of children with refractory partial epilepsy. Int J Pharm Pharm Sci 2014;6:119-22.

16. Sindhu B, Patnaik A, Subrahmanyam KV, Pattnaik P. Validated HPLC technique for determination of drug rufinamide: Applications to 
stability studies. Int J Innov Pharm Sci Res 2014;2:2691-9.

17. Patel A, Suhagia DB, Patwari A. Development and validation of stability indicating HPLC method for estimation of rufinamide in bulk and its pharmaceutical dosage form. World J Pharm Res 2014;3:1798-810.

18. Rajpura P. Analytical method development and validation for assay of rufinamide drug. Management 2013;1:191-203.

19. Kumar BS, Annapurna MM, Pavani S. Development and validation of a stability indicating RP-HPLC method for the determination of rufinamide. J Pharm Anal 2013;3:66-70.

20. Yanamadala G, Sravya J. Development and validation of a stability indicating RP-HPLC method for quantification of lamotrigine in bulk and pharmaceutical dosage form. World J Pharm Pharm Sci 2014;3:1502-15

21. Reddy T, Ramu G, Babu AB, Rambabu C. Development and validation of HLPC method for the estimation of lamotrigine in bulk and pharmaceutical formulations. J Chem 2012;2013. Article ID: 846170, 4.

22. Patel A, Kataria M. RP-HPLC method development and validation of lamotrigine in tablet dosage form. Int J Adv Res Pharm BioSci 2012;1:95-102.

23. Kumar DA, Kumar CV, Seetharamaiah P, Rao JS. Estimation of lamotrigine by RP-HPLC method. J Chem 2010;7:S203-S8.

24. Patil PM, Wankhede SB, Chaudhari PD. A validated stabilityindicating HPLC method estimation of clonazepam in the bulk drug and pharmaceutical dosage form. Pharm Anal Acta 2015;6:332.

25. Lazar M, Mouzdahi A, Zahouily M. Development and validation of a RP-HPLC method for the determination of clonazepam and related impurities in a pharmaceutical formulation. Asian J Res Biol Pharm Sci 2013;1:9-18
26. Uma MK, Lakshmana RP, Balamurali KK, Rambabu C. New validated Rp-Hplc method for the estimation of diazepam in dosage forms. Indo Am J Pharm Res 2014;4:4054-9.

27. Sruthi A, Tejaswi P, Thanuja N, Kumar DS, Sagar PV. Simple RP-HPLC method for estimation of diazepam in tablet dosage form. J Pharm Res 2013;6:140-4.

28. Lazar M, Mouzdahir A, Zahouily M. Method development and validation of diazepam in tablet dosage form by HPLC. Asian J Pharm Anal Med Chem 2013;1:140.

29. Thakkar R, Saravaia H, Ambasana M, Patel M, Shah A. An isocratic method for quantification of valproic acid and its related impurities using ion pair reagent by ultraperformance liquid chromatography. ISRN Chromatogr 2012;2012. Article ID: 836132, 5.

30. Karde M, Pawar H, Geevarghese R, Khatri J. Development and validation of RP-HPLC method for estimation of valproic acid in dissolution study of its formulation. Int J Pharm Pharm Sci 2012;4 Suppl 5:201-6.

31. Gupta RK, Kumar S, Singh UK, Iqbal K, Sethia S. Reverse phase high performance liquid chromatographic method for the estimation of valproic acid in bulk drug and soft gelatin capsules. Pharm Chem 2010;2:22-7.

32. Gupta R, Singh U, Kumar S, Moothan B. Estimation of sodium valproate in tablet dosage form by RP-HPLC without prior derivatization: Application to dissolution studies. Int J Pharm Sci Drug Res 2009;1:103-6.

33. (ICH) Guidelines Q2 (R1). Validation of Analytical Procedures: Text and Methodology; 2005. 